\title{
UPAYA PENINGKATAN HASIL BELAJAR DAN AKTIVITAS SiSWA DALAM PEMBELAJARAN FISIKA MELALUI MODEL GUIDED DISCOVERY LEARNING DENGAN METODE PRAKTIKUM KELAS XI - IPA SMAN 106 JAKARTA
}

\author{
Suripta*) \\ SMAN 106 JAKARTA \\ ka_sma_106@yahoo.com
}

\begin{abstract}
This research is entitled "effors to improve learning Outcomes and Student Activity on Physycs through Learning Model Discovery Learning Practicum Methode class XI-IPA SMAN 106 Jakarta. "This research as a breakethrough in increasing creativity of learning management, base on the curriculum 2013. The prosess is directed to produce Indonesian people who are productive, creative, innovative, affective through strengthening integrated attiude, skills and knowledge. Thus the educators must improve the creativity of teaching methodes so that students are not bored and motivate student learning. Base on this discription, it is hope that the teacher is able to play role as on innovator through learning. This study uses a qualitative approach to optain data and analysis through reflective, participatory and collaborative studies. Program development is base on data and information from students, teachers and social setting naturally through twoncycles off classroom research, each of which is planning, implementing, observing and reflecting. To enhance the learning outcomes and student activities in learning physycs of action research, this class(CAR) presents Learning Guided Discovery learning Model Practicum Methode. This research was conducted at SMAN 106 Jakarta with two cycles. In the first cycle, some student are not familiar with the learning condition that use Learning Guided Discovery Learning Model Practicum Mthode. In the second cycle, progress has been seen in the learning process and student beging to creat learning condition that lead to learning approach of Learning Guided Discovery Learning Model Practicum Methode. From observations student activities increased from 45,14 \% in the pre-cycle to 74,69\% in cycle 1 and $76,74 \%$ in cycle 2. While the learning outcomes or daily assessment experienced an average increase of 66 in the pre-cycle assessment(before using the learning Guided Discovery Learning Model Practicum Methode) to 80,25 in the first cycle an average 84,06 in the 2 cycle. From this implemtation of Classroom Action Research(CAR), the first cycle, the second cycle can be concluded thad the Guided Discovery LearningModel Practicum Methode can improve learning outcomes and student activity in Physics learning at SMAN 106 Jakarta.
\end{abstract}

Keywords: learning outcomes,student activites, and learnin model of guided discovery learning practicum method

Nazhruna: Jurnal Pendidikan Islam

Vol. 2 No 1 2019. Issn: 2614-8013. Hal. 136-163

DOI: $10.3153 /$ nzh.v2i1.253 


\begin{abstract}
Abstrak
Penelitian ini berjudul "Upaya Peningkatan HasilBelajar dan Aktivitas Siswa dalam Pembelajaran Fisika melalui Pembelajaran Model Guided Discovery Learning Metode Praktikum Kelas XI-IPA SMAN 106 Jakarta”. Penelitian ini berangkat dari perlunya sebuah terobosan dalam peningkatan kreativitas dalam pengelolaan pembelajaran agar tuntutan pembelajaran sesuai tuntutan kurikulum 2013, dimana proses pembelajaran diarahkan agar dapat menghasilkan insan Indonesiayang : produktif, kreatif, inovatif afektif melalui penguatan sikap, keterampilan dan pengetahuan terintregasi. Dengan demikian pendidik harus meningkatakan kreativitas metode mengajar agar siswa tidak jenuh dan dapat memotivasi belajar siswa. Berdasar uraian di atas, melalui penelitian ini diharapkan guru mampu memainkan peranan sebagai innovator pembelajaran. Penelitian ini menggunakan pendekatan kualitatif untuk mendapatkan data dan analisisnya melalui kajian-kajian reflektif, partisipatif dan kolaboratif. Pengembangan program berdasar pada data-data dan informasi siswa, guru dan seting social kelas ssecara alamiah melalui tahapan : perencanaan, pelaksanaan, pengamatan dan refleksi. Untuk meningkatkan hasil belajar dan aktivitas siswa dalam pembelajaran fisika di Penelitian Tindakan Kelas ini menggunakan Pembelajaran Model Guided Discovery Learning Metode Praktikum. Penelitian ini dilakukan di SMAN 106 Jakarta dengan menggunakan dua siklus. Pada siklus pertama sebagian siswa belum terbiasa dengan kondisi belajar yang menggunakan Pembelajaran Model Guided Discovery Learning Metode Praktikum. Dalam silus kedua sudah terlihat kemajuan dalam proses pembelajaran, dimana aktivitas siswa mulai ada peningkatan. Hal ini terlihat dari pengamatan siswa mulai terbiasa menciptakan kondisi belajar yang mengarah pada pendekatan Pembelajaran Model Guided Discovery Learning Metode Praktikum. Dari pengamatan aktivitas siswa mmeningkat dari $45,14 \%$ pada prasiklus menjadi 74,6 \% pada sklus 1 dan menjadi 76,74\% pada siklus 2. Sementara dari hasil belajar atau penilaan harian mengalami peningkatan rata-rata 66 pada penilaian prasiklus(sebelum menggunakan Pembelajaran Model Guided Discovery Learning Metode Praktikum) menjadi 80,25 pada siklus pertama dan rata-rata 84,06 pada sklus kedua. Dari pelaksanaan penelitian tindakan kelas ini siklus pertama, siklus kedua dapat disimpulkan bahwa Pembelajaran Model Guided Discovery Learning Praktikum dapat meningkatkan hasil belajar dan aktivitas siswa dalam pembelajaran fisika pada SMAN 106 Jakarta.
\end{abstract}

Kata kunci: hasil belajara, aktivitas siswa, dan pembelajaran model guided discovery, metode praktikum 


\section{Pendahuluan}

Belajar merupakan suatu proses yang wajib dijalani seseorang dari sejak lahir hingga meninggal dunia yang diharapkan dengan belajar akan merubah cara hidupnya menjadi lebih baik, dari yang belum tahu menjadi tahu, dari kurang baik menjadi baik. Menurut teori belajar tingkah laku atau aliran behaviorisme, belajar adalah perubahan dalam tingkah laku sebagai akibat dari interaksi antara stimulus dan respon. Seseorang dikatakan sudah mmengalami proses belajar jika telah mampu bertingkah laku dengan cara baru sebagai hasil interaksi antara stimulus berupa proses dan materi pembelajaran dengan respon atau tanggapan yang diberikan oleh pembelajar. Belajar merupakan suatu proses perubahan tingkah laku, menambah wawasan dari yang belum tahu menjadi tahu dan menerapkannya dalam kehidupan sehari-hari.

Hasil belajar peserta didik sangat menjadi perhatian bagi pendidik untuk mengetahui apakah dia mampu mencapai hasil belajar yang baik selama proses pembelajaran. Tidak hanya itu hasil belajar dalam kelas harus dapat dilaksanakan ke dalam situasi-situasi di luar sekolah. Dengan kata lain, murid dapat mentransferkan hasil belajar itu ke dalam situasi-situasi yang sesungguhnya di dalam masyarakat .

Pembelajaran fisika dipandang sebagai suatu proses untuk mengembangkan kemampuan memahami konsep, prinsip maupun hukum-hukum fisika sehingga dalam proses pembelajarannya harus mempertimbangkan strategi atau metode pembelajaran yang efektif dan efisien. Pembelajaran fisika di sekolah menengah merupakan salah satu mata pelajaran IPA yang dapat menjadi wahana bagi siswa untuk mempelajari diri sendiri dan alam sekitar. Dalam pembelajaran fisika, pengalaman proses sains dan pemahaman produk sains dalam bentuk pengalaman langsung akan sangat berarti dalam membentuk konsep siswa. Hal ini juga sesuai dengan tingkat perkembangan mental siswa SMA yang berada pada fase transisi dari konkrit ke formal, akan sangat memudahkan siswa jika pembelajaran Sains mengajak anak untuk belajar merumuskan konsep secara induktif berdasar fakta.

Untuk itu guru harus dapat memilih suatu pendekatan maupun metode pembelajaran dalam belajar fisika agar dapat memberikan pengalaman proses sains dan pemahaman produk sains dalam bentuk pengalaman langsung dalam membentuk konsep siswa. Pembelajaran yang dapat mengajak anak untuk belajar merumuskan konsep secara induktif berdasar fakta . 
Disamping proses pembelajaran yang dapat mengajak anak untuk belajar merumuskan konsep secara induktif berdasar fakta, pembelajaran juga harus dapat meningkatkan aktivitas siswa. Meningkatnya aktivitas siswa dalam proses pembelajaranakan membuat pelajaran lebih bermakna, karena (1) adanya keterlibatan siswa dalam menyusun dan membuat perencanaan proses belajar mengajar, (2) adanya keterlibatan intelektual melalui dorongan semangat yang dimiliknya, (3) adanya keikutsertaan siswa secara kreatif dalam mendengarkan dan memperhatikan apa yang disajikan guru.

Dilihat dari hasil belajar pada ranah kognitif (pengetahuan ) yang telah dicapai pada siswa pada ulangan harian pada KD: 3.2. Menganalisis sifat elastisitas bahan dalam kebidupan sehari hari, rata-rata nilai ulangan kelas adalah 66 siswa yang belum mencapai ketuntasan dalam pembelajaran berjumlah 22 siswa ( $61.11 \%$ dari 36 siswa) sedangkan yang tuntas adalah 14 siswa ( $38.89 \%$ dari 36 siswa). Hal ini mengindikasikan bahwa dalam proses pembelajaran ada beberapa kendala yang menyebabkan siswa belum mencapai ketuntasan.

Untuk itu perlu dicari solusi agar pembelajaran fisika dapat menumbuhkan kemampuan berpikir kreatif dan dapat meningkatkan aktivitas siswa. Salah satu solusi yang dapat dilaksanan adalah pembelajaran koperatif dengan metode praktikum. Oleh karena itu perlu diadakan penelitian tindakan kelas untuk membuktikan bahwa melalui penerapan model pembelajaran guided discovery learning dengan metoda eksperimen dapat meningkatkan hasil belajar dan aktivitas siswa dalam pembelajaran fisika.

Berdasarkan latar belakang di atas, maka rumusan masalah dalam penelitian ini adalah: (1). Bagaimana penerapan model pembelajaran guided discovery learning dengan metoda praktikum dapat meningkatkan hasil belajar dan aktivitas siswa dalam pembelajaran fisika ? (2). Apakah penerapan model pembelajaran guided discovery learning dengan metoda ptaktikum dapat meningkatkan hasil belajar dan aktivitas siswa dalam pembelajaran fisika?.

Tujuan penelitian ini adalah untuk: (1) Mengetahui minat belajar siswa dengan menggunakan pembelajaran discovery learning dengan metoda eksperimen; Mengetahui hasil belajar siswa ditinjau dari pembelajaran discovery learning dengan 
metoda eksperimen; (3). Pengaruh pembelajaran discovery learning dengan metoda praktikum terhadap peningkatan hasil belajar maupun aktivitas belajar siswa.

Manfaat yang diharapkan dari penelitian ini: (1) Bagi Peneliti; Peneliti dapat memahami pelaksanaan pembelajaran fisika melalui model pembelajaran discovery learning dengan metoda praktikum, sehingga bisa mandiri dalam menyelesaikan permasalahan yang ada.

(2) bagi guru : (a)Memperbaiki pembelajaran yang dikelolanya;(b)Dapat berkembang secara profesional karena dapat menunjukkan bahwa guru mampu menilai dan memperbaiki pembelajaran yang dikelolanya; (c) Guru mampu melaksanakan analisis terhadap kinerjanya sendiri di dalam kelas, sehingga menemukan kelebihan dan kelemahan yang kemudian mengembangkan pengetahuan dan ketrampilan sendiri; (d) Guru mendapat kesempatan untuk berperan aktif mengembangkan pengetahuan dan ketrampilan sendiri; (e)Guru dapat menggunakan model pembelajaran pembelajaran discovery learning dengan metoda eksperimen sebagai salah satu alternatif untuk mengembangkan kemampuan dalam memecahkan masalah dan dapat dijadikan pedoman dalam menerapkan model pembelajaran pembelajaran guided discovery learning dengan metoda praktikum; (3) bagi sekolah (a) Memperbaiki praktik pembelajaran dengan sasaran akhir; (b) Memperbaiki belajar siswa, sehingga lebih dapat meningkatkan kemampuan siswa; (c) Siswa mampu mengembangkan potensi kemampuan dalam menyelesaikan masalah secara mandiri. (4) Bagi Sekolah; (a) Memberikan sumbangan pemikiran sebagai alternatif untuk meningkatkan kualitas pembelajaran di sekolah; (b) Sekolah memiliki bermacam-macam variasi model pembelajaran.

Penelitian ini dibangun berdasarkan kajian beberapa teori yakni: (1) pengertian belajar; (2) hasil belajar; (3) aktivitas belajar; (4)model pembelajaran;(5) model pembelajaran discovery learning; (6) Model Pembelajaran Guided Dicovery Learning; (7) Metode Pembelajaran; (8) Metode Pembelajaran Praktikum; (9) Pembelajaran Fisika

Pengertian belajar menurut Skiner dalam Kompri dapat didefinisikan sebagai suatu adaptasi atau penyesuaian tingkah laku yang berlangsung secara progresif. Dari pernyataan Skiner dalam Wahab Jufri di atas, belajar dapat diartikan sebagai suatu usaha seseorang dalam memperoleh perubahan tingkah laku secara keseluruhan 
dalam hidupnya yang merupakan hasil dari pengalaman dalam berinteraksi dengan lingkungan hidupnya (Kompri, Motvasi Pembelajaran, hlm. 217 ) $^{1}$

Teori tentang belajar ini juga dikemukakan oleh Sardiman dalam Kompri, yaitu belajar adalah serangkaian kegiatan jiwa raga untuk memperoleh suatu perubahan tingkah laku sebagai hasil dari pengalaman individu dalam interaksi dengan lingkungannya yang menyangkut kognitif, afektif, dan psikomotor.( Kompri, Motivasi Pembelajaran, hlm. 219.) ${ }^{2}$

Berdasarkan definisi belajar dari beberapa ahli yang telah dipaparkan diatas, dapat disimpulkan bahwa belajar merupakan proses yang dialami seseorang secara alamiah dan mutlak yang dapat merubah pola pikir dan tingkah laku seseorang ke arah yang lebih baik dari sebelumnya. Melalui belajar seseorang dapat memperteguh kelakuannya melalui pengalaman yang ada, memanfaatkan pengetahuan yang dimilikinya dan menerapkannya dengan format yang baru.

Hasil belajar menurut Bloom mencakup kemampuan kognitif, afektif dan psikomotorik.Domain kognitif adalah knowledge (pengetahuan, ingatan), comprehension (pemahaman, menjelaskan, meringkas, contoh), application (menerapkan), analysis (menguraikan, menentukan hubungan), sinthesis (mengorganisasikan, merencanakan, membentuk bangunan baru), dan evaluation (menilai). Domain afektif adalah receiving (sikap menerima), responding (memberikan respons), valuing (nilai), organization (organisasi), characterization (karakterisasi). Domain psikomotor meliputi initiatory, preroutine, dan rountinized. Psikomotor juga mencakup keterampilan produktif, teknik fisik, sosial, manajerial, dan intelektual.

Hasil belajar menurut Jenkin dan Uwin dalam buku Donni Juni Priansa (2017) menyatakan bahwa hasil belajar adalah pola-pola perbuatan, nilai-nilai, pengertian-pengertian, sikap-sikap, apresiasi, dan keterampilan.( Donni Juni Priansa, hlm. 81) $)^{3}$

Hasil belajar mencakup apa yang terdapat pada setiap diri individu dari mulai perbuatan yang dilakukannya, nilai-nilai yang terdapat pada dirinya, pengertian, sikap,

${ }^{1}$ Kompri, Motivasi Pembelajaran, PT Remaja Rosda Karya, Bandung, 2015.

${ }^{2}$ Kompri, Motivasi Pembelajaran, PT Remaja Rosda Karya, Bandung, 2015.

3 Juni Priansa, Donni, Pengembangan Strategi \& Model Pembelajaran, Pustaka Setia, Bandung, 2017. 
apresiasi serta keterampilan yang dimilikinya. Hasil belajar juga merujuk kepada lima hal yaitu tentang informasi verbal, keterampilan intelektual, strategi kognitif, keterampilan motorik, dan sikap dari seseorang individu. Perubahan ini akan terjadi pada individu yang melakukan proses belajar dan menerapkan apa yang telah didapatkan dalam kehidupannya

Aktivitas belajar adalah seluruh kegiatan yang dilakukan untuk mencapai tujuan pembelajaran. Peningkatan aktivitas siswa dalam pembelajaran adalah meningkatnya jumlah siswa yang aktif dalam proses pembelajaran, antara lain banyaknya siswa yang bertanya, banyaknya siswa yang saling berinteraksi membahas materi pelajaran.

Rousseau dalam Sardiman mengatakan aktivitas belajar adalah segala pengetahuan itu harus diperoleh dengan pengamatan sendiri, pengalaman sendiri, dengan fasilitas yang diciptakan sendiri, baik secara rohani maupun teknis ( Sardiman AM, hlm. 98) ${ }^{4}$

Paul B. Diedrich dalam Ngalimun membagi kegiatan belajar siswa dalam 8 kelompok yang meliputi :(a) Visual activities, yang termasuk di dalamnya seperti ;(b) membaca,memperhatikan gambar, demonstrasi, percobaan;(c) Oral activities, seperti menyatakan, merumuskan, bertanya, memberi saran, mengeluarkan pendapat, mengadakan wawancara, diskusi,interupsi;(d) Listening activities, seperti mendengarkan;(e) Writing activities, seperti menulis cerita;(f) Drawing activities, seperti menggambar, membuat grafik dan membuat diagram; (g) Motor activities, seperti melakukan percobaan, membentuk konstruksi,model mereparasi, bermain dan berkebun; (h) Mental activities, seperti menanggapi, mengingat, memecahkan soal,menganalisis dan mengambil keputusan;(h) Emotional activities, seperti minat, merasa bosan dan bersemangat, (Ngalimun, hal.38 $)^{5}$

Model pembelajaran merupakan kerangka konseptual dan operasional pembelajaran yang memiliki nama, ciri,urutan logis, pengaturan, dan budaya. Model pembelajaran menurut Ngalimun adalah suatu perencanaan atau suatu pola yang

\footnotetext{
${ }^{4}$ Sardiman, AM, Interaksi dan Motivasi Belajar Mengajar, Jakarta: PT.Raja Grafindo Persada, 2014

${ }^{5}$ Ngalimun, Strategi dan Model Pembelajaran, Aswaja Presindo, Jogyakarta, 2016.
} 
digunakan sebagai pedoman dalam merencanakan pembelajaran di kelas (Ngalimun, hal.24) ${ }^{6}$

Dengan kata lain, model pembelajaran adalah suatu perencanaan atau pola yang dapat kita gunakan untuk mendesain pola-pola mengajar secara tatap muka di kelas dan untuk menentukan material/perangkat pembelajaran termasuk didalamnya buku-buku, media pembelajaran

Model pembelajaran memiliki ciri-ciri sebagai berikut (1)asional teoritik yang logis yang disusun oleh penciptaan atau pengembangan (2) Landasan pemikiran tentang apa dan bagaimana siswa belajar(tujuan pembelajaran yang akan dicapai (3) Tingkah laku yang diperlukan agar model tersebut dapat dilaksanakan secara berhasil (4) Lingkungan belajar yang diperlukan agar tujuan pembelajaran dapat tercapai.

Model discovery merupakan pembelajaran yang menekankan pada pengalaman langsung dan pentingnya pemahaman struktur atau ide-ide penting terhadap suatu disiplin ilmu, melalui keterlibatan siswa secara aktif dalam pembelajaran. Bahan ajar yang disajikan dalam bentuk pertanyaan atau permasalahan yang harus diselesaikan. Jadi siswa memperoleh pengetahuan yang belum diketahuinya tidak melalui pemberitahuan, melainkan melalui penemuan sendiri. Bruner (dalam Kemendikbud, 2013 b: 4$)^{7}$.

Prosedur Penerapan model discovery learning (a) Stimulation (stimulasi/pemberian rangsangan) (b) Problem statement (pernyataan/ identifikasi masalah) (c) Data collection (Pengumpulan Data). (d) Data Processing (Pengolahan Data) (e) Verification (Pembuktian) (f) Generalization (menarik kesimpulan/generalisasi) Pembelajaran Penemuan terbimbing (guided Dicovery Learning) adalah suatu model pemebelajaran dimana pesertadidik menemukan suatu konsep atau teori, pemahaman, dan pemecahan masalah secara aktif dan mandiri. Proses penemuan tersbut membutuhkan guru sebagai fasilitator dan pembimbing. Beberapa definisi lain tentang pembelajaran Penemuan terbimbing ( guided Dicovery Learning ) adalah

${ }^{6}$ Ngalimun, Strategi dan Model Pembelajaran, Aswaja Presindo, Jogyakarta, 2016.

${ }^{7}$ Kemendikbud, Materi pelatihan Implementasi kurikulum 2013, Jakarta,2015 
sebagai berikut ( Ngalimun, dkk, Strategi dan Model Pembelajaran, Aswaja Presindo, Yogyakarta, 2016, hal.265) ${ }^{8}$.

Hamalik (2001)menyatakan bahwa penemuan terbimbing melibatkan pesertadidik dalam menjawab pertanyaan-pertanyaan guru.Pesetadidik melakukan penemuan, sedangkan guru membimbing pesertadidik kearah yang tepat/benar

Hanafiah dan Suhana(2010) menyatakan bahwa pembelajaran terbimbing merupakan pelaksanaan penemuan yang dilakukan atas petunjuk dari guru. Pembelajarannya dimulai dai guru mengajukan berbagai pertanyaan yang melacak, untuk mengarahkan peserta didik kepada titik kesimpulan, kemudian peserta didik melakukan percobaan untuk membuktikan yang dikemukan.

Sedang Bruner (dalam Ngalimu : 2016) menyatakan bahwa tahap-tahap dalam implementasi pembelajaran terbimbing adalah sebagai berikut (1) Stimulus, yaitu memberikan pertanyaan atau menganjurkan pesertadidik untuk mengamati gambar ataupum membaca buku mengenai materi; (2) Pernyaaan maslah, berkaitan dengan pemberian esempatan kepada pesertadidik untuk mengidentifikasi sebanyak mungkin masalh yang relevan dengan bahan pelajaran, kemudian memilih dan merumuskan nya dalam bentuk hipotesis; (3) Pengumpulan data, berkaitan dengan pemberian kesempatan kepada pesertadidik mengumpulkan informasi; (4) Pemrosesan data, berkaitan dengan pengolahan data yang telah diperoleh oleh pesertadidik; (5) Verifikasi, berkaitan dengan pemeriksaan secara cermat untuk membuktikan benar tidaknya hipotesis; (6) Generalisasi, berkaitan dengan penarikan simpulan dari proses pembelajaran yang telah dilakukan

Sedang menurut Ngalimun : " Metode adalah satu cara yang dipergunakan untuk mencari tujuan pembelajaran yang telah ditetapkan" (Ngalimun, dkk, Strategi dan Model Pembelajaran, Yogyakarta :Aswaja Presindo, , 2016, hal.13) ${ }^{9}$. Penentuan metode yang akan digunakan oleh guru dalam proses pembelajaran akan sangat menentukan berhasil atau tidaknya pembelajaran yang berlangsung.

Sedang menurut Kompri:" Metode merupakan sebentuk cara yang digunakan untuk mengungkapkan sesuatu kepada orang lain dengan teknik dan pola tertentu.” Guru sebagai pengajar juga memanfaatkan metode untuk mencapai tujuan

${ }^{8}$ Ngalimun, Strategi dan Model Pembelajaran, Aswaja Presindo, Jogyakarta, 2016.

9 Ngalimun, Strategi dan Model Pembelajaran, Aswaja Presindo, Jogyakarta, 2016. 
pembelajaran (Kompri, Motivasi Pembelajaran,Bandung: PT.Rosda Karya, 2015, hlm. 56) ${ }^{10}$

Metoda Praktikum merupakan pengajaran yang bertujuan supaya siswa mendapatkan kesempatan untuk menguji dan melaksanakan di keadaan nyata. Cara mengajar dengan metode praktikum lebih memberikan kesempatan kepada siswa untuk menemukan fakta yang ingin diketahui

Pendapat Zainal Aqib tentang metode praktikum menyatakan bahwa metode praktikum merupakan sebuah pembelajaran dengan cara praktik yang menggunakan alat-alat tertentu. Peran guru dalam pembelajaran ini adalah melatih keterampilan siswa dalam menggunakan alat-alat tersebut. Selain itu, guru juga bertugas untuk memberikan hasil belajar yang bisa dicapai oleh mereka (Zainal Aqib , hlm. 114) ${ }^{11}$

Menurut Sumiati dan Asra dalam bukunya menyatakan bahwa metode praktikum merupakan pembelajaran verbal dalam rangka meningkatkan kemampuan hasil belajar yang dicapai melalui latihan dan praktek. Menurut mereka, praktikum biasanya dilakukan dalam situasi yang nyata sehingga memberikan pengalaman langsung bagi yang menjalankannya. Praktikum ini bisa dilakukan secara individu atau kelompok. Metode praktikum ini bisa mengambangkan kecakapan atau keahlin yang dimiliki siswa( Sumiati dan Asra, hlm. 104.) ${ }^{12}$

Pembelajaran fisika dipandang sebagai suatu proses untuk mengembangkan kemampuan memahami konsep, prinsip maupun hukum-hukum fisika sehingga dalam proses pembelajarannya harus mempertimbangkan strategi atau metode pembelajaran yang efektif dan efisien. Pembelajaran fisika di sekolah menengah pertama merupakan salah satu mata pelajaran IPA yang dapat menjadi wahana bagi siswa untuk mempelajari diri sendiri dan alam sekitar. Dalam pembelajaran fisika, pengalaman proses sains dan pemahaman produk sains dalam bentuk pengalaman langsung akan sangat berarti dalam membentuk konsep siswa. Hal ini juga sesuai dengan tingkat perkembangan mental siswa SMA yang masih berada pada fase transisi dari konkrit ke formal, akan sangat memudahkan siswa jika pembelajaran

${ }^{10}$ Kompri, Motivasi Pembelajaran, PT Remaja Rosda Karya, Bandung, 2015.

11 Zainal Aqib dan Ali Murtadlo, Kumpulan Metode Pembelajaran Kreatif dan Inovatif, Bandung: Irama Widya

${ }^{12}$ Sumiati dan Asra, Metode Pembelajaran, Bandung: Wacana Prima, 2008 
Sains mengajak anak untuk belajar merumuskan konsep secara induktif berdasar fakta-fakta empiris di lapangan

\section{Metode Penelitian}

Penelitian Tindakan Kelas (PTK) dilaksanakan di kelas XI SMAN 106 Jakarta. Sample yang menjadi objek penelitian adalah siswa kelas XI - IPA SMAN 106 Jakarta yang berjumlah 36 siswa dengan kondisi yang heterogen. Penelitian itu sendiri berlangsung dari bulan September sampai dengan Nopember 2017 dengan menggunakan instrument penelitian berupa angket, lembar observasi dan tes.

Penelitian ini adalah penelitian tindakan kelas. Penelitian Tindakan Kelas yang dalam Bahasa Inggris biasa disebut Clasroom Action Research (CAR) adalah penelitian tindakan (action research)yang dilakukan dengan tujuan memperbaiki mutu praktik pembelajaran di kelasnya. Penelitian ini memusatkan objek penelitiannya kepada semua hal yang ada di dalam kelas, baik yang fisik maupun non fisik. Yaitu semua hal yang terjadi di dalam kelas ketika pembelajaran sedang berlangsung. Pada prinsipnya diterapkan PTK atau CAR (Clasroom Action Research)dimaksudkan untuk mengatasi suatu permasalahan yang terdapat didalam kelas . Di dalam Penelitian Tindakan Kelas (PTK) terdapat beberapa model atau desain penelitian yang digunakan ketika peneliti melakukan PTK. Desain-desain tersebut diantaranya adalah: (1) Model Kurt Lewin, (2) Model Kemmis Mc Taggart, (3) Model John Elliot, (4) Model Hopkins, (5) Model McKernan, (6) Model Dave Ebbut. Dalam hal ini, peneliti disini melakukan PTK dengan menggunakan model Kemmis and Mc Taggart. (Suharsimi Arikunto dkk,Penelitian Tindakan Kelas(Jakarta: Bumi Aksara, 2010). 


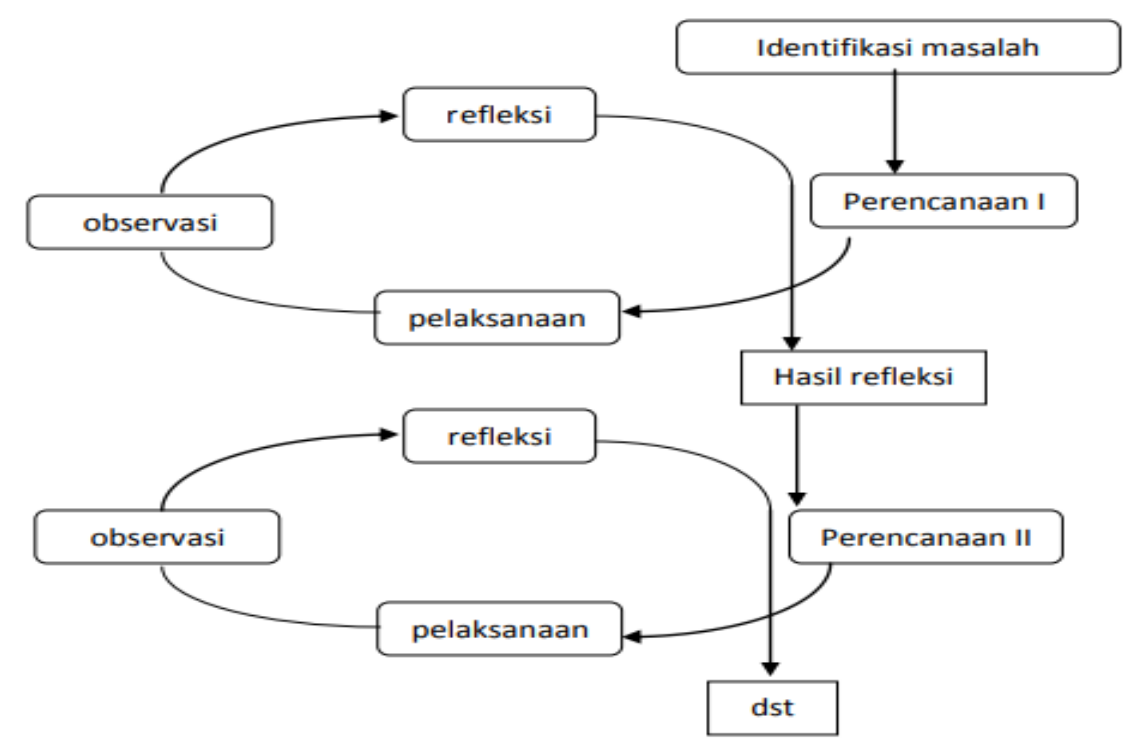

Gambar 1. Model Penelitian model Kemmis and Mc Taggart.

Jumlah siklus dalam penelitian ini adalah dua siklus dengan prosedur penelitian yang terdiri dari: perencanaan, pelaksanaan, observasi dan evaluasi, serta analisis dan refleksi

Peneliti dalam perencanaan melakukan hal-hal sebagai berikut: (1) mengidentifikasi problem yang dialami peserta didik dalam pembelajaran Fisika di kelas kelas XI - IPA 2 semester ganjil SMAN 106 Jakarta; (2) merumuskan pilihan tindakan yang dilakukan dalam usaha meningkatkan hasil belajar dan aktivitas siswa dalam pembelajaran menggunakan model Pembelajaran Guided Dicovery Learning Metode Praktikum (3) melakukan penyusunan silabus dan RPP pada KD 3.3. Menerapkan hukum-hukum fluida statik dalam kehidupan seharihari pada siklus pertama dan KD 3.4 Menerapkan prinsip fluida dinamik dalam teknologi pada siklus kedua (4) menentukan metode pengumpulan data dan analisis data.

Data yang dikumpulkan adalah data (a) Data hasil tes, yaitu data hasil tes hasil belajar ranah kognitif pada Kompetensi dasar 3.2 Menganalisis sifat elastisitas bahan dalam kehidupan sehari hari untuk prasiklus, Kompetensi dasar 3.3 Menerapkan hukumhukum fluida statik dalam kehidupan seharihari untuk siklus 1 dan Kompetensi dasar 3.4 Menerapkan prinsip fluida dinamik dalam teknologi untuk siklus 2;(b) data angket respon siswa, yaitu data hasil angket dengan siswa untuk mengetahui keterlaksanaan pembelajaran; (c) data observasi, data obervasi aktivitas siswa dalam pembelajaran dan keterlaksanaan proses pembelajaran 
Sumber data dalam penelitian ini terdiri dari beberapa sumber, yaitu siswa, guru dan teman sejawat serta kolaborator.(a) Primer: hasil tes, angket, observasi, wawancara; (b) Sekunder: data dari sumber lain: buku, online, dokumen, dll

PTK ini terdiri dari tiga siklus dengan membandingkan hasil post-test tiap siklus I, II, dan III dengan hasil yang integral. Tiap akhir siklus dilakukan analisis dan refleksi berdasarkan observasi peneliti dan kolaborator.

Penelitian Tindakan Kelas (PTK) dilakukan sesuai jadwal mengajar peneliti sebanyak 6 kali pertemuan pada semester genap. Materi PTK ialah 3.2 Menganalisis sifat elastisitas bahan dalam kehidupan sehari hari untuk prasiklus, Kompetensi dasar 3.3 Menerapkan hukumhukum fluida statik dalam kehidupan seharihari untuk siklus 1 dan Kompetensi dasar 3.4 Menerapkan prinsip fluida dinamik dalam teknologi untuk siklus 2pada standar isi dan kegiatan pembelajaran sesuai RPP yang sudah disusun.

Tahap observasi dan evaluasi dilaksanakan oleh peneliti sendiri, bekerja sama dengan guru sebagai teman sejawat. Tahap analisis dan refleksi hasil observasi dari observer serta nilai post-test tiap akhir siklus dijadikan bahan refleksi melalui diskusi peneliti dan observer/kolaborator

Dalam pengumpulan data penelitian peneliti menggunakan teknik (a) Tes,Teknik pengumpulan data dengan menggunakan tes tertulis untuk mengetahui hasil belajar setelah siswa mengikuti pembelajaran dalam satu siklus (posttest). Tes yang digunakan berupa soal pilihan ganda. Soal di buat untuk menegetahui hasil belajar siswa pada pembelajaran yang telah dilaksanakan. Penilaian pada setiap akhir siklus juga bertujuan untuk mengukur peningkatan belajar siswa setelah dilakukan tindakan pembelajaran pada setiap siklus;(b) Observasi, adalah kegiatan pengamatan (pengambilan data) untuk memotret seberapa jauh efek tindakan telah mencapai sasaran. Lembar observasi ini berguna untuk pengamatan (pengambilan data) dalam kemampuan berpikir kritis siswa dalam proses pembelajaran, pengamatan aktivitas siswa dan untuk pengamatan kegiatan aktivitas guru selama proses pembelajaran. Selain itu, lembar observasi berguna untuk mengetahui kesesuaian pelaksanaan tindakan dengan rencana pelaksanaan pembelajaran (RPP) yang telah disusun sebelumnya; (c) Angket, Pengertian angket berdasarkan depdikbud tahun 1975 adalah suatu alat pengumpul data yang berupa serangkaian pertanyaan yang diajukan pada 
responden untuk mendapat jawaban. Angket adalah suatu alat yang dignakan untuk mengumpulkan data dengan cara membuat daftar pertanyaan secara tertulis dan lalu oleh narasumber (read : responden) akan diisi dengan cara tertulis pula. Oleh masyarakat luas, angket sering kali juga disebut dengan sebutan Quesioner.Angket dalam penelitian ini dimaksudkan untuk mengetahui sejauh mana respon siswa terhadap pembelajaran dengan menggunakan model guided discovery learning dengan metoda praktikum;(d)Dokumen, Dokumentasi merupakan cara pengumpulan data sebagai bukti kegiatan yang dilakukan selama penelitian. Dokumentasi bisa berbentuk tulisan, gambar, atau karya-karya monumental dari seseorang. Dokumentasi foto merupakan instrumen nontes yang cukup penting, yaitu sebagai bukti kegiatan selama pembelajaran berlangsung, maupun kegiatan yang dilaksnakan selama penelitian

Penelitian ini dikatakan berhasil apabila memenuhi indikator proses dan indikator output sebagai berikut: (1) Indikator Proses; Indikator proses dalam penelitian ini untuk melihat tingkat keberhasilan selama proses pembelajaran, meliputi indicator keberhasilan respon siswa, indicator keberhasilan aktivitas siswa, indicator keberhasilan RPP dan indicator keberhasilan penilaian pelaksanaan pembelajaran;(2) indikator keberhasilan meliputi: keberhasilan guru dalam mengelola pembelajaran, keberhasilan belajar siswa

Angket Respon Siswa ,Indicator proses dari respon siswa dalam penelitian ini dinyatakan sebagai berikut: (1) Jika respon siswa memperoleh nilai 85-100\% maka ditetapkan kategori sangat baik;(2) Jika respon siswa memperoleh nilai 70-84\% maka ditetapkan kategori baik;(3) Jika respon siswa memperoleh nilai 50-69\% maka ditetapkan kategori cukup;(4) Jika respon siswa memperoleh nilaisangat baik

Lembar Observasi Aktivitas Siswa(1) Jika rata-rata aktivitas siswa secara keseluruhan memperoleh angka 85-100\% maka ditetapkan kategori sangat baik;(2) Jika rata-rata aktivitas siswa secara keseluruhan memperoleh angka 70-84\% maka ditetapkan kategori baik;(3)Jika rata-rata aktivitas siswa secara keseluruhan angka 5069\% maka ditetapkan kategori cukup;(4)Jika rata-rata aktivitas siswa secara keseluruhan memperoleh angka $<49 \%$ maka ditetapkan kategori kurang.

Dokumen Guru, Untuk mengetahui indikator keberhasilan Rencana Pelaksanaan Pembelajaran (RPP), kriteria penilaian dapat dilakukan dengan format sebagai berikut: (1) Jika rencana pelaksanaan pembelajaran memperoleh nilai 85- 
100\% maka ditetapkan kategori sangat baik;(2) Jika rencana pelaksanaan pembelajaran memperoleh nilai 70-84\% maka ditetapkan kategori baik; (3) Jika rencana pelaksanaan pembelajaran memperoleh nilai 50-69\% maka ditetapkan kategori cukup; (4) Jika rencana pelaksanaan pembelajaran memperoleh nilai $<49 \%$ ditetapkan kategori kurang

Keberhasilan guru dalam mengelola pembelajarandapat diukur melalui lembar aktifitas guru yang berisi langkah-langkah yang dilakukanguru dalam proses pembelajaran atau lembar keterlaksanaan rencana pembelajaran. Lembar ini harus dilaksanakan oleh guru dan pelaksanaan pembelajaran tersebut akan diamati oleh peneliti. Dalam penelitian ini, yang bertindak sebagai peneliti adalah guru bidang studi fisika. Untuk mengetahui indikator keberhasilan pelaksanaan pembelajaran, kriteria penilaian dapat dilakukan dengan format sebagai berikut: (1) Jika pelaksanaan pembelajaran memperoleh nilai 85-100\% maka ditetapkan kategori sangat baik.; (2) Jika pelaksanaan pembelajaran memperoleh nilai 70-84\% maka ditetapkan kategori baik;(3) Jika pelaksanaan pembelajaran memperoleh nilai 50-69\% maka ditetapkan kategori cukup; (4) Jika pelaksanaan pembelajaran memperoleh nilai $<49 \%$ ditetapkan kategori kurang

Keberhasilan belajar siswa, Untuk mengetahui sampai dimana tingkat keberhasilan belajar siswa terhadap proses belajar yang telah dilakukannya menggunakan acuan tingkat keberhasilan sebagai berikut: (1)Sangat baik : apabila hasil belajar siswa mencapai 95 s.d 100\%;(2) Cukup baik: apabila hasil belajar siswa mencapai $85 \%$ s.d $94 \%$;(3) Baik: apabila hasil belajar siswa mencapai $75 \%$ s.d $84 \%$; (4) Kurang : apabila hasil belajar siswa mencapai kurang dari $75 \%$.

\section{Hasil dan Pembahasan}

Hasil belajar sebelum adanya tindakan kelas dilakukan dapat dilihat pada

Tabel 1.

Tabel 1 .Nilai awal siswa

\begin{tabular}{|l|c|}
\hline Rerata & $\mathbf{6 6 , 0 0}$ \\
\hline Ketuntasan & $38.89 \%$ \\
\hline Tidak Tuntas & $61.11 \%$ \\
\hline Terendah & 42 \\
\hline Tertinggi & 80 \\
\hline
\end{tabular}


Sedangkan Hasil pengamatan aktivitas siswa dalam pembelajaran sebelum diberi tindakan dapat dilihat pada tabel 2 .

Tabel 2. Hasil Pengamatan Aktivitas siswa dalam pembelajaran prasiklus.

\begin{tabular}{|c|c|c|c|c|c|c|c|c|c|}
\hline \multirow[b]{2}{*}{ Kelmpok } & \multicolumn{9}{|c|}{ Aktivitas (\%) } \\
\hline & \begin{tabular}{|c|} 
Visual \\
aktivitas
\end{tabular} & \begin{tabular}{|l} 
Listening \\
activities
\end{tabular} & \begin{tabular}{|l} 
Emotional \\
Aktivities
\end{tabular} & \begin{tabular}{|l} 
Writing \\
activities
\end{tabular} & $\begin{array}{l}\text { Oral } \\
\text { activities }\end{array}$ & $\begin{array}{c}\text { Motor } \\
\text { activites }\end{array}$ & $\begin{array}{l}\text { Drawing } \\
\text { activities }\end{array}$ & $\begin{array}{c}\text { Menthal } \\
\text { Activities }\end{array}$ & RERATA \\
\hline KELOMPOK 1 & 100,00 & 83,33 & 50,00 & 83,33 & 50,00 & 0,00 & 0,00 & 0,00 & 45,83 \\
\hline KELOMPOK 5 & 100,00 & 66,67 & 50,00 & 33,33 & 83,33 & 16,67 & 0,00 & 0,00 & 43,75 \\
\hline KELOMPOK 3 & 100,00 & 50,00 & 50,00 & 50,00 & 50,00 & 16,67 & 0,00 & 0,00 & 39,58 \\
\hline KELOMPOK 4 & 100,00 & 66,67 & 50,00 & 50,00 & 83,33 & 0,00 & 0,00 & 0,00 & 43,75 \\
\hline KELOMPOK 5 & 100,00 & 66,67 & 50,00 & 66,67 & 83,33 & 0,00 & 0,00 & 0,00 & 45,83 \\
\hline KELOMPOK 6 & 100,00 & 83,33 & 66,67 & 50,00 & 83,33 & 0,00 & 0,00 & 33,33 & 52,08 \\
\hline Rata-rata & 100,00 & 69,44 & 52,78 & 55,56 & 72,22 & 5,56 & 0,00 & 5,56 & 45,14 \\
\hline
\end{tabular}

Siklus I pertemuan pertama dimulai dengan perencanaan pembelajaran sesuai silabus dan RPP KD 5.yaitu fluida statis dengan materi tekanan hidrostatis dan hukum utama hidrostatis. Peneliti melakukan kegiatan : melakukan analisis untuk menentukan Kompetensi Dasar yang akan diajarkan kepada siswa melalui model Pembelajaran Discovery learning dengan metode praktikum, membuat rencana pembelajaran dengan pembelajaran Discovery learning dengan metode praktikum, membuat LKS, membuat intrumen yang akan digunakan dalam siklus PTK, menyusun evaluasi pembelajaran

Pada tahap pelaksanaan pertemuan pertama dilaksanakan sesuai langkah kegiatan yang sudah dibuat sesuai RPP. Setelah guru membagi kedalam 6 kelompok guru membagi LKS. Siswa diminta melakukan praktikum tanpa dijelaskan terlebih dahulu. Selam siswa melakukan kegiatan, guru berkeliling untuk membimbing setiap kelompok yang bertanya. Pada pertemuan pertama ini ada beberapa kelompok siswa mengalami kesulitan dalam malakukan kegiatan praktikum yaitu : (1) Cara membuat lubang yang diameternya tidak sama;(2) Jarak lubang dari dasar botol;(3) Pada saat melepas tutup lubang;(4) Cara mengukur jatuhnya air dari lubang botol;(5) Ada beberapa kelompok yang belum bekerja secara sistematis. Kemudian guru meminta 
salah satu kelompok mempresentasikan hasil kerja kelompoknya dan menyampikan kesimpilan.Kemudian guru membimbing peserta didik menarik kesimpulan pelajaran hari itu dan mengakhiri pembelajaran dengan berdo'a dan salam.

Pada tahap pengamatan, guru dan kolaborator mengamati aktivitas peserta didik dalammpembelajaran dan mencatat pada lembar pengamatan aktivitas siswa.Sedang kolaborator juga mengamati apakah kegiatan yang dilakukan guru seuai dengan langkah kegiatan pada RPP. Pada tahap refleksi, guru memeriksa, menganalisis hasil catatan aktivitas siswa dan langkah kegiatan guru dalam pembelajaran.

Siklus I pertemuan kedua materi pembelajaran adalah Hukum Pascal dan Hukum Archimides. Pada pelaksanaan pada pertemuan kedua setelah LKS dibagikan siswa terlebih dahulu diminta membaca kemudian salah satu siswa dalam suatu kelompok diminta untuk mendemontrasikan percobaan yang akan dilakukan, kemudian guru menambah penjelasan. Setelah kegiatan ini siswa diminta melakukan percobaan dan pengamatan. Selama siswa melakukan praktikum, guru berkeliling setiap kelompok untuk memberikan bebrapa penjelasan bagi kelompok yang belum jelas dalam pelaksanaan praktikum. Lembar kerja siswa diharapkan dapat membantu siswa menggali konsep Hukum Pascal dan Hukum Archimides serta penerapannya dalam kehidupan sehari-hari. Setelah selesai, siswa bersama-sama membahas lembar aktivitas siswa (LAS) yang telah dikerjakan serta meminta salah satu kelompok presentasi dan menyampaikan kesimpulan. Pada akhir kegiatan guru membantu mengabil kesimpulan dan membantu membuat rangkuman. Pada tahap pengamatan, guru mengamati mengamati jalannya pembelajaran secara berkeliling saat kelompok sudah mulai beraktivitas baik kerja ilmiah serta diskusi. Kolaborator memberi saran untuk perbaikan berjalannya kelompok sesuai dengan teknik pembelajaran.Tahap refleksi dilaksanakan sama dengan pelaksanaan refleksi pada pertemuan pertama

Siklus I pertemuan ketiga materi pembelajaran adalah meniskus, gejala kapilaritas,Viskositas dan bukum Stokes. Pada pelaksanaan pada pertemuan kedua setelah LKS dibagikan siswa terlebih dahulu diminta membaca kemudian salah satu siswa dalam suatu kelompok diminta untuk mendemontrasikan percobaan yang akan dilakukan, kemudian guru menambah penjelasan. Setelah kegiatan ini siswa diminta melakukanpercobaan dan pengamatan. 
Tahap pengamatan, guru mengamati kegiatan pembelajaran, mengamati aktivitas siswa dan membimbing peserta didik selama siswa melakukan praktikum. Kolaborator mengamati aktivitas guru dalam pembelajaran serta membantu mengamati aktivitas siswa dalam pembelajaran. Guru berkeliling setiap kelompok untuk memberikan beberapa penjelasan bagi kelompok yang belum jelas dalam pelaksanaan praktikum. Lembar kerja siswa diharapkan dapat membantu siswa menggali konsep yang ada di buku serta memahami tentang yang miniskus, kapilaritas dan viskositas yang ada dalam kehidupan sehari-hari. Setelah selesai, siswa bersama-sama membahas LKS yang telah dikerjakan serta menyimpulkannya

Tahap refleksi, guru memeriksa hasil catatan aktivitas siswa maupun aktivitas guru dalam pembelajaran, serta hasil tes dan membandingkan dengan tes-tes sebelumnya. Menganalisis catatan aktivitas siswa maupun aktivitas guru dalam pembelajaran untuk mengetahui peningkatan aktivitas siswa dalam pembelajaran. Menganalisis hasil tes mengenai kemajuan pembelajaran,an menginformasikan hasil tes dan kerja kelompok yang sudah berhasil dan meningkat serta memberi apresiasi keberhasilan peserta didik sebagai reward.

Siklus II pertemuan pertama, dengan materi penerapan hukum bernoulli pada tahap perencanaan sama dengan siklus pertama. Tahap pelaksanaan sama dengan siklus pertama karena aktivitas siwa dalam pembelajaran,hasil belajar, sudah menunjukan kemajuan dbandingkan pada prasiklus . Sedangkan kegiatan guru dalam pembelajaran sudah sesuai dengan langkah kegiatan pada RPP

Pada tahap pengamatan, guru mengamati aktivitas siswa dan mengarahkan peserta didik melakukan kegiatan. Kolabarator mengamati kegiatan guru dan membantu mengamati aktivitas siswa. Tahap refleksi, memeriksa, menganalisis catatan hasil aktivitas siswa serta langkah kegiatan guru.

Siklus II pertemuan kedua, tahap perencanaan materi pembelajaran adalah penerapan hukum bernouli sama dengan siklus pertama. Pada pelaksanaan pada pertemuan kedua setelah LKS dibagikan siswa terlebih dahulu diminta membaca kemudian salah satu siswa dalam suatu kelompok diminta untuk mendemontrasikan percobaan yang akan dilakukan, kemudian guru menambah penjelasan. Setelah kegiatan ini siswa diminta melakukanpercobaan dan pengamatan. Untuk tahap pelaksanaan dilakukan sama dengan pertemuan pertama. Pada tahap pengamatan, 
guru mengamati aktivitas siswa dan mengarahkan peserta didik melakukan kegiatan. Kolabarator mengamati kegiatan guru dan membantu mengamati aktivitas siswa. Tahap refleksi, memeriksa, menganalisis catatan hasil aktivitas siswa serta langkah kegiatan guru.

Siklus II pertemuan ketiga, pada tahap perencanaan, dengan materi KD. 3.7 memformulasikan prinsip kerja penyemprot parfum dan penyemprot nyamuk sama dengan pertemuan kedua. Tahap pelaksanaan sama dengan setting pada pertemuan kedua. Pada tahap pengamatan, guru mengamati aktivitas siswa dan mengarahkan peserta didik melakukan kegiatan. Kolabarator mengamati kegiatan guru dan membantu mengamati aktivitas siswa. Tahap refleksi, memeriksa, menganalisis catatan hasil aktivitas siswa serta langkah kegiatan guru.

Rekapitulasi hasil pengamatan aktivitas siswa dalam pembelajaran pada prasiklus, siklus I, siklus II, dapat dilihat pada table 3 berikut.

Tabel 3 Aktivitas Belajar Siswa rata-rata prasiklus, siklus 1 dan siklus 2

\begin{tabular}{|c|c|c|c|c|c|c|c|c|c|c|c|c|c|c|c|c|c|c|c|c|c|c|c|c|c|c|c|}
\hline \multirow{3}{*}{ Kelmpok } & \multicolumn{27}{|c|}{ Tabel Aktivitas rata-rata prasikikus, siklus 1 dan siklus 2} \\
\hline & \multicolumn{3}{|c|}{ Visual aktivitas } & \multicolumn{3}{|c|}{ Listening activities } & \multicolumn{3}{|c|}{ Emotional Aktivities } & \multicolumn{3}{|c|}{ Writing activities } & \multicolumn{3}{|c|}{ Oral activities } & \multicolumn{3}{|c|}{ Motor activites } & \multicolumn{3}{|c|}{ Drawing activities } & \multicolumn{3}{|c|}{ Menthal Activities } & \multicolumn{3}{|c|}{ RERATA KLASSIKAL. } \\
\hline & Pra & Siklus & Siklus & $\mathrm{Pra}$ & Siklus & Siklus & Pra & Siklus & Siklus & Pra & Siklus & Siklus & $\mathrm{Pra}$ & Siklus & Siklus & $\mathrm{Pra}$ & Siklus & Siklus & $\mathrm{Pra}$ & Siklus & Siklus & $\mathrm{Pra}$ & Siklus & Siklus & Pra & Siklus & Siklus \\
\hline 7 & 100,00 & 100,00 & 100,00 & 83,33 & 100,00 & 100,00 & 50,00 & 83,33 & 83,33 & 83,33 & 83,33 & 83,33 & 50,00 & 66,67 & 72,22 & 0,00 & 83,33 & 83,33 & 0,00 & 50,00 & 50,00 & 0,00 & 55,56 & 83,33 & 45,83 & 77,78 & 81,94 \\
\hline ELOMPOK 5 & 100,00 & 100,00 & 100,00 & 66,67 & 33,33 & 83,33 & 50,00 & 66,67 & 66,67 & 33,33 & 66,67 & 66,67 & 83,33 & 83,33 & 83,33 & 16,67 & 66,67 & 66,67 & 0,00 & 83,33 & 88,89 & 0,00 & 50,00 & 50,00 & 43,75 & 75,00 & 75,69 \\
\hline KELOMPOK 4 & 100,00 & 100,00 & 100,00 & 66,67 & 83,33 & 83,33 & 50,00 & 83,33 & 83,33 & 50,00 & 66,67 & 66,67 & 83,33 & 83,33 & 83,33 & 0,00 & 66,67 & 66,67 & 0,00 & 66,67 & 66,67 & 0,00 & 6,67 & 66,67 & 43,75 & 77,08 & 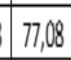 \\
\hline KELOMPOK5 & 100,00 & 100,00 & 100,00 & 66,67 & 100,00 & 100,00 & 50,00 & 61,11 & 66,67 & 66,67 & 83,33 & 83,33 & 83,33 & 83,33 & 83,33 & 0,00 & 50,00 & 50,00 & 0,00 & 50,00 & 50,00 & 0,00 & 66,67 & 72,22 & 45,83 & 74,31 & 75,69 \\
\hline KELOMPOK 6 & 100,00 & 100,00 & 100,00 & 83,33 & 94,44 & 100,00 & 66,67 & 83,33 & 88,89 & 50,00 & 50,00 & 55,56 & 83,33 & 83,33 & 83,33 & 0,00 & 72,22 & 66,67 & 0,00 & 55,56 & 50,00 & 33,33 & 50,00 & 50,00 & 52,08 & 73,61 & 74,31 \\
\hline RERRTA & 100,00 & 100,00 & 100,00 & 69,44 & 92,59 & 94,44 & 52,78 & 75,00 & 78,70 & 55,56 & 68,52 & 70,37 & 72,22 & 77,78 & 78,70 & 5,56 & 70,37 & 69,44 & 0,00 & 59,26 & 61,11 & 5,56 & 56,48 & 62,04 & 45,14 & 75,00 & 76,85 \\
\hline
\end{tabular}




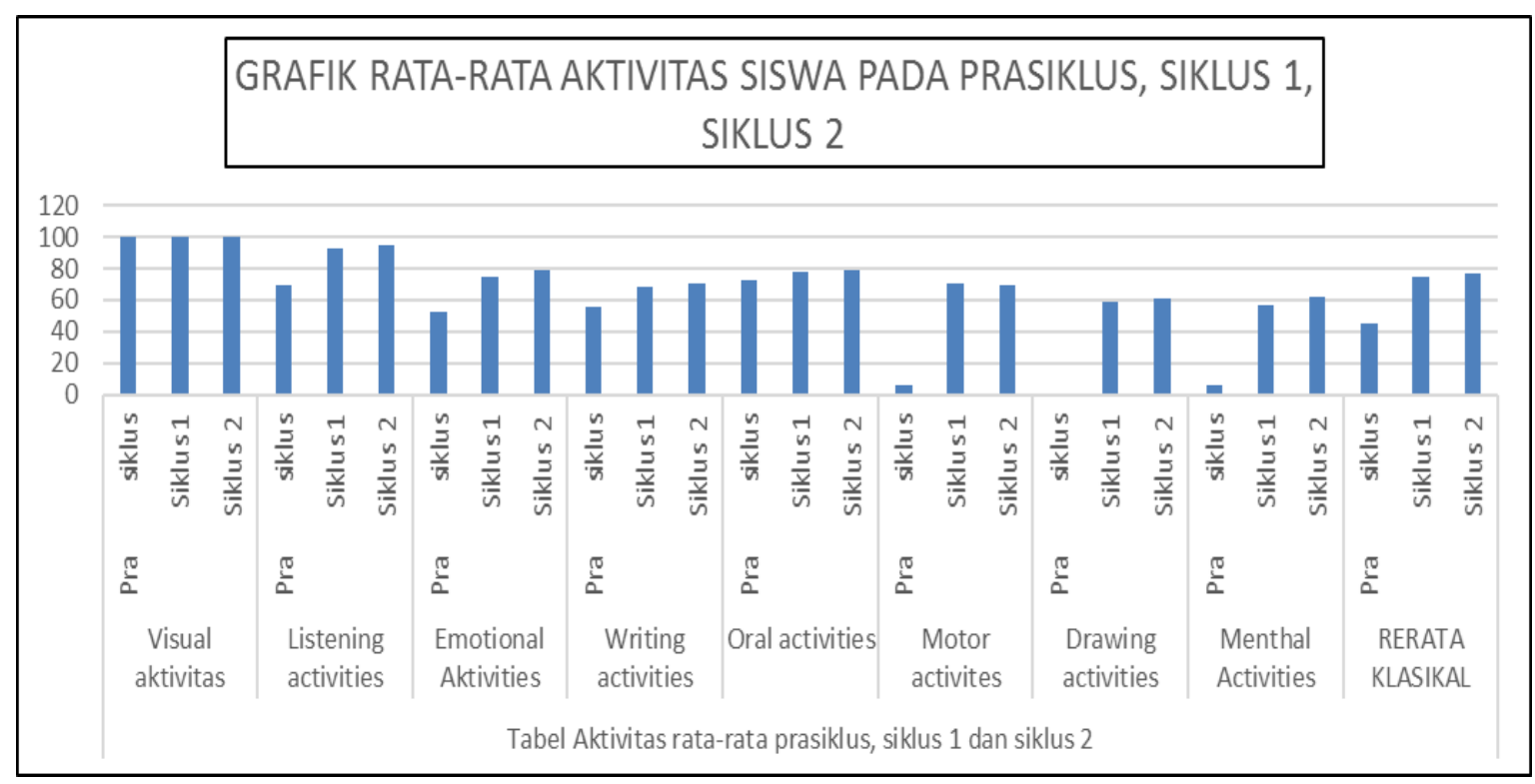

Gambar 2. Grafik Aktivitas Belajar Siswa pada prasiklus ,siklus 1 dan siklus 2

Dilihat tabel 2, bahwa aktivitas rata-rata pada siklus 2 mengalami kenaikan sebesar 1,85\% dari rerata siklus 1, yaitu dari 75,00\% pada siklus 1 menjadi 76,85\% pada siklus 2, hal dapat dikatakan bahwa penerapan pembelajaran model guided discovery learning metode praktikum dapat meningkatkan aktivitas siswa dalam pembelajaran.

Jika dilihat dari masing- masing aktivitas siswa dalam pembelajaran maka visual aktivities memeroleh hasil 100\%. Hal ini berate dalam kegiatan yang termasuk visual aktivities yang meliputi : Membaca teks bacaan/Petunjuk Kegiatan seluruh siwa melakukan, karena sebelum kegiatan praktikumdimulai seluruh siswa diminta membaca petunjuk kegiatan agar didalam pelaksanaan kegiatan praktikum tidak mengalami kesulitan .

Untuk aktivitas berupa Listening activities yang meliputi Perhatian siswa terhadap penjelasan guru baik siklus 1 dan siklus 2 diatas $90 \%$, hanya sedikit siswa ketika diberi penjelasan dari guru kurang antusias dalam mendengarkan penjelasan guru. Hal ini dapat teramati ketika guru menjelaskan, siswa asik dengan dunianya sendiri seperti memainkan pensil maupun ngobrol dengan temannya.

Untuk aktivitas siswa yang berupa Emotional Aktivities, antara lain berupa Antusiasme siswa dalam proses pembelajajaran masih di bawah 80\%, akan tetapi 
diatas 75\%, hal ini berarti sudah mencapai batas ketuntasan yang dipersaratkan . Aktivitas ini bias diamati ketika siswa melakukan kegiatan praktikm maupun diskusi. Jika siswa aktif dalam diskusi atau berpartisipasi aktif dalam praktikum berarti siswa menunjukan antusiasme dalam proses pembelajaran.

Sedang Writing activities yang berupa Menulis materi pelajaran dapat diamati ketika guru menjelaskan materi, siswa mencatat atau tidak. Hal ini bias teramati dengan jelas apakah ada bukti catatan atau tidak pada buku catatn siswa. Pada Writing activities diperoleh hasil yang belum memenuhi batas ketuntasan, karena dari hasil pengamatan pada siklus1 sebesar 68,52\% pada siklus 2 sebaesar 70, 37\%. Hal ini kadang siswa dalam suatu kelompok mengandalkan temannya atau penjelasan guru yang berupa slide di papan tulis akan difoto dan di share melau WA group dalam kelas.

Oral activities yang berupa Mengungkapkan pendapat dengan kata sendiri dapat diamati ketika mereka diskusi kelompok atau diskusi kelas. Tingkat ketuntasan pada indicator ini mencapai 7,78\% pada siklus 1 dan 78, 70\% pada siklus 2 . Hal ini berarti untuk indicator Oral activities sudah mencapai batas ketuntasan yang dipersaratkan yaitu sebesar $75 \%$. Jika dilihat dari prasilus, siklus 1 dan siklus 2 oral activities sudah mengalami kenaiakan. Artinya dengan dengan metode praktikum siswa dapat menjelaskan suatu konsep dengan bahasanya sendiiri berdasar fakta-fakta yang teramati dari hasil praktikum.

Untuk indikator aktivitas siswa yang berupa Motor activites yang meliputi Partisipasi dalam diskusi, dapat diamati ketika siswa melakukan diskusi , baik diskusi kelompok atau diskusi kelas. Jika siswa banyak mengemukan pendapat, menanya, atau menjawab pertanyaan dari temnnya berate siswa sangat partisipatif dalam pembelajaran. Untuk aktivitas ini dari hasil yang diperoleh dari observasi diperoleh hasil yang kurang baik, yaitu 70,37\% pada siklus 1 dan 69, $44 \%$ pada siklus 2 . Pada siklus 2 mengalami penurunan sebesar $0,93 \%$. Pada indicator ini belum mencapai batas ketuntasan, karena di bawah $75 \%$.

Untuk aktivitas Drawing activities yang berupa menyimpulkan berdasar pengamatan diperoleh hasil 59, $26 \%$ pada siklus 1 dan 61,11\% pada siklus 2. Pada indikator ini juga masih dibawah batas ketuntasan yaitu masih dibawah $75 \%$, Memang pada indikator ini merupakan suatu aktivitas yang paling berat, karena siswa 
dituntut mampu membuat kesimpulan berdasar hasil kegiatan pembelajaran atau setelah kegiatan praktikum.

Pada indikator Menthal Activities yang berupa Mempresentasiakan hasil pengamatan diperoleh hasil 56,48\% pada siklus 1 dan 62,04\% pada siklus 2 . Pada indicator ini memang tidak bias semua kelompok dapat mempresentasikan hasil karena keterbatasan waktu. Tetapi dilihat dari siklus 1 dan siklus 2 terjadi kenaikan karena setelah ditawarkan kelompok siapa yang akan mempresentasikan hasil banyakmjuga kelompok yang bersedian tampil, baik secara individu maupun kelompok.

Perbandingan hasil belajar peserta didik pada siklus I, siklus II dapat dilihat pada table 4 berikut :

Tabel 4. Tabel hasil tes pada prasiklus, siklus 1 dan siklus 2

\begin{tabular}{|c|c|c|c|c|}
\hline \multirow{2}{*}{ No } & \multirow{2}{*}{ Rentang nilai } & \multicolumn{3}{|c|}{ Frekuensi } \\
\cline { 3 - 5 } & & Pra siklus & Siklus 1 & Siklus 2 \\
\hline 1 & $91-100$ & - & 3 & 9 \\
\hline 2 & $81-90$ & - & 21 & 17 \\
\hline 3 & $71-80$ & - & 7 & 8 \\
\hline 4 & $61-70$ & 22 & 1 & - \\
\hline 5 & $51-60$ & 10 & 2 & 2 \\
\hline 6 & $\leq 50$ & 4 & 2 & - \\
\hline 7 & Nilai tertinggi & 70 & 94 & 96 \\
\hline 8 & Nilai terendah & 40 & 41 & 58 \\
\hline 9 & Rerata & 62,17 & 80.25 & 84,06 \\
\hline
\end{tabular}




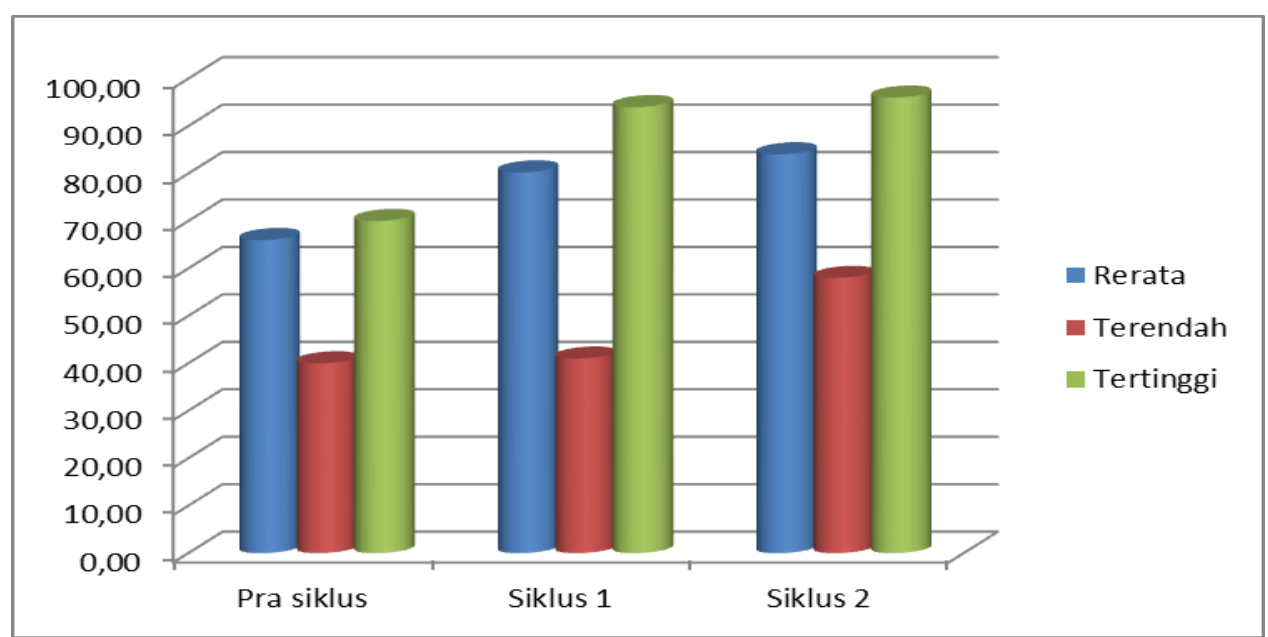

\section{Gambar 3. Grafik hasil belajar pada prasiklus, siklus 1 dan siklus 2}

Berdasarkan hasil tes yang diberikan pada table 4, dapat diketahui bahwa ratarata hasil belajar siswa menunjukkan nilai sebesar 62,17 pada prasiklus, 80.25 pada siklus 1 dan 84,06 pada siklus 2. Hal ini menunjukkan bahwa hasil belajar siswa berdasarkan kemampuan kognitif sudah mencapai indikator keberhasilan.

Dilihat hasil tes pada siklus 1 dan siklus 2 pada tabel 4. dapat disimpulkan bahwa hasil belajar siswa mengalami kenaikan setelah perlakuan pembelajaran diberikan dibanding pada tes hasil belajar prasiklus. Hal ini dapat dikatakan bahwa model pembelajaran guided discovery learning dengan metode praktikum dapat meningkatkan hasil belajar siswa.

Untuk keberhasilan dalam proses pembelajaran juga dapat dilihat dari respon siswa dalam mengikuti proses pembelajaran. Hal ini dapat dilihat dari hasil angket siswa sebagaiman tertera dalam tabel 5 berikut.

Tabel 5. Tabel hasil angket respon siswa terhadap pembelajaran dengan model guided discovery learning metode praktikum setelah siklus 2

\begin{tabular}{|c|l|c|}
\hline No & \multicolumn{1}{|c|}{ Pernyataan } & $\begin{array}{c}\mathbf{1} \\
\text { Ketercapaian }\end{array}$ \\
\hline $\mathbf{1}$ & $\begin{array}{l}\text { Model Guided Discovery Learning (GBL) dengan metode } \\
\text { praktikum lebih bermanfaat untuk belajar Fisika }\end{array}$ & $\mathbf{8 7}$ \\
\hline $\mathbf{2}$ & Belajar Fisika dengan menggunakan model GDL membuat & $\mathbf{8 5}$ \\
\hline
\end{tabular}




\begin{tabular}{|c|c|c|}
\hline No & Pernyataan & $\begin{array}{c}\% \\
\text { Ketercapaian }\end{array}$ \\
\hline & saya lebih terampil & \\
\hline 3 & $\begin{array}{l}\text { Model Guided Discosery Learning (GBL) dengan metode } \\
\text { praktikum mendorong saya untuk menemukan ide-ide baru }\end{array}$ & 75 \\
\hline 4 & $\begin{array}{l}\text { Belajar Fisika menggunakan model Guided Discovery Learning } \\
\text { (GBL) dengan metode praktikum membuat saya lebih } \\
\text { memahami materi }\end{array}$ & 77 \\
\hline 5 & $\begin{array}{l}\text { Belajar Fiska menggunakan model Guided Discovery Learning } \\
\text { (GBL) dengan metode praktikum saya merasa lebih } \\
\text { termotivasi }\end{array}$ & 72 \\
\hline 6 & $\begin{array}{l}\text { Belajar Fisika dengan model Guided Discovery Learning (GBL) } \\
\text { dengan metode praktikum dapat mengeksplorasi diri saya } \\
\text { sendiri }\end{array}$ & 74 \\
\hline 7 & $\begin{array}{l}\text { Belajar Fisika dengan menggunakan model Guided Discovery } \\
\text { Learning (GBL) dengan metode praktikum melatih saya untuk } \\
\text { bisa mengemukakan pendapat }\end{array}$ & 78 \\
\hline 8 & $\begin{array}{l}\text { Belajar Fisika menggunakan model Guided Discovery Learning } \\
\text { (GBL) dengan metode praktikum membuat saya lebih aktif } \\
\text { dalam belajar }\end{array}$ & 82 \\
\hline 9 & $\begin{array}{l}\text { Belajar Fisika menggunakan model Guided Discovery Learning } \\
\text { (GBL) dengan metode praktikum membuat materi mudah } \\
\text { diingat }\end{array}$ & 73 \\
\hline 10 & $\begin{array}{l}\text { Model Guided Discovery Learning (GBL) dengan metode } \\
\text { praktikum membuat pelajaran Fisika lebih menarik untuk } \\
\text { dipelajari }\end{array}$ & 80 \\
\hline & Rata-rata & 78,33 \\
\hline
\end{tabular}




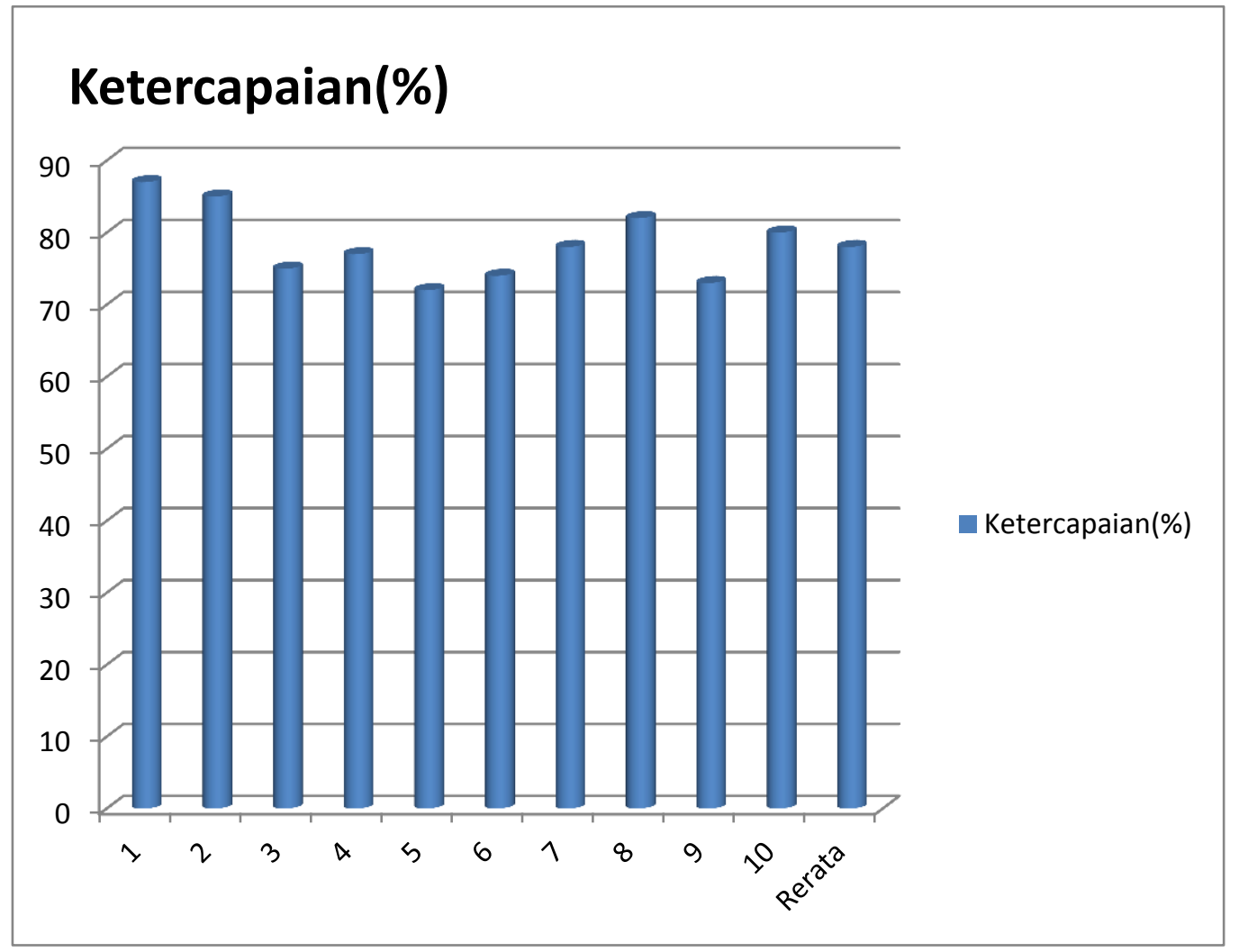

Gambar 4. Grafik hasil angket respon siswa terhadap pembelajaran dengan model guided discovery learning setelah siklus 2

Dilihat dari hasil angket respon siswa terhadap pembelajaran dengan model guided discovery learning metode praktikum setelah siklus 2, diperoleh hasil rata-rata 78,33\%. Dengan mengacu pada indikator keberhasilan angket respon yang telah ditetapkan yaitu : Jika respon siswa memperoleh nilai 70-84\% maka ditetapkan kategori baik, maka bisa dikatakan respon siswa terhadap pembelajaran dengan model guided discovery learning adalah baik. 


\section{Simpulan}

Berdasarkan analisis data dan pembahasan yang telah diuraikan sebelumnya, maka dapat disimpulkan bahwa pembelajaran fisika dengan menggunakan model discovery learning melalui metode praktikum dapat meningkatkan aktivitas belajar dan hasil belajar siswa. Selain itu, berdasarkan data observasi, dapat terlihat bahwa pembelajaran fisika dengan menggunakan model guided discovery learning melalui metode praktikum pada siklus II lebih baik dibandingkan dengan siklus I. Hal ini terjadi karena pada siklus II terdapat perbaikan tindakan yang dilakukan oleh guru, seperti pengaturan waktu yang lebih proporsional, peningkatan pengawasan guru terhadap seluruh siswa dan memeriksa bahwa semua siswa memahami tujuan dan prosedur kegiatan yang harus dilakukan, memberikan motivasi kepada siswa serta adanya pembagian tugas yang merata kepada anggota kelompok masing-masing sehingga semua siswa terlibat dalam memecahkan masalah dan memperhatikan proses penemuan yang dilakukan.

Aktivitas belajar siswa pada prasiklus mencapai ketercapaian 45,14\%,pada siklus $176,9 \%$ dan pada siklus 276,74\%. Berarti aktivitas siswa dalam pembelajaran mengalami kenaikan setelah mengalami perlakuan dengan model guided discovery learning dengan metode praktikum.

Peningkatan hasil belajar siswa juga dapat dilihat berdasarkan nilai rata-rata hasil belajar yang diperoleh siswa pada pembelajaran sebelumnya (tanpa menggunakan guided discovery learning) dari 62,17 menjadi 80,25 pada siklus I dan 84,06 pada siklus II.

Sedang berdasar angket respon siswa dalam pembelajaran mencapai 78,33 \% dengan kategori baik. Hal ini berarti pembelajaran dengan model guided discovery learning dengan metode praktikum dapat diterima dengan baik oleh siswa.

Dengan demikian, maka berdasarkan data-data di atas dapat disimpulkan bahwa aktivitas belajar siswa dan hasil belajar siswa mengalami peningkatan dengan menggunakan model guided discovery learning melalui metode praktikum karena telah mencapai kriteria indikator keberhasilan yang telah ditetapkan.

Guru hendaknya memperhatikan fasilitas dan lingkungan belajar siswa untuk mendukung peningkatan kualitas pembelajaran melalui variasi model dan metode pembelajaran, menggunakan metode yang cocok bagi siswa dan pokok bahasan yang 
sedang dipelajari, menggunakan metode maupun media yang bervariasi untuk mencegah munculnya kebosanan pada siswa dan suasana belajar akan lebih menyenangkan.

Dalam proses pembelajaran sebaiknya situasi belajar berpindah dari situasi teacher dominated learning menjadi situasi belajar student dominated learning, guru lebih memotivasi siswa untuk belajar lebih baik sehingga hasil belajar akan meningkat.

Dalam pelaksanaan pembelajaran dengan menggunakan model guided discovery learning melalui metode praktikum seorang guru harus benar-benar memperhatikan aktivitas belajar yang dilakukan siswa dengan optimal.

\section{Referensi}

Abdullah Sani, Ridwan, Demontrasi dan Ekperimen Fisika, Bumi Aksara Group, Jakarta, 2016.

Aqib, Zainal, Penelitian Tindakan Kelas, Yrama Widya, Jakarta, 2007

, Penelitian Tindakan Sekolah, Yrama Widya, Jakarta, 2009

Hamzah, Ali dan Muhlisrarini, Perencanaan dan Strategi Pembelajaran Matematika, Raja Grafindo Persada, Jakarta, 2014.

Hilmina, Upaya Meningkatkan Hasil Belajar Kimia dengan Metode Discovery Learning Melalui Kegiatan Laboratorium Pada Konsep Sistem Koloid; penelitian Tndakan Kelas di MAN 12 Jakarta Barat Kelas XI, UIN Syarif Hidayatullah, Jakarta, 2011.

Juni Priansa, Donni, Pengembangan Strategi \& Model Pembelajaran, Pustaka Setia, Bandung, 2017.

Kunandar, Penelitian Tindakan Kelas, Rajagrafindo Persada, Jakarta, 2008.

Kompri, Motivasi Pembelajaran, PT Remaja Rosda Karya, Bandung, 2015.

Kosasih, E, Strategi Belajar dan Pembelajaran, Yrama Widya, Bandung, 2016

Kemendikbud, Materi pelatihan Implementasi kurikulum 2013, Jakarta,2015

Kemendikbud, Model silabus Mata Pelajaran Fisika, 2017

Liena Andiasari, Jurnal Kebijakan dan Pengembangan Pendidikan "Penggunaan Model Inquiry dengan Metode Eksperimen dalam Pembelajaran IPA di SMPN 10 Probolinggo" (Volume 3, Nomor 1, Januari 2015, ISSN: 23377623; EISSN: 2337-7615. 
Maria Angela Sangi Pedha, Skripsi "Penerapan metoda Praktikum untuk meningkatkan hasil belajar dan Karaktr peserta didik pada materi pokok gaya kelas VII SMP Negeri Wanukaka” (Universitas Sanata Darma Yogyakarta, 2017

Moh.Yamin, Teori dan Metode Pembelajaran, Madani, Malang, 2014,

Ngalimun, Strategi dan Model Pembelajaran, Aswaja Presindo, Jogyakarta, 2016.

Sanjaya, Wina, Strategi Pembelajarana, Kencana Prenada Media, Jakarta, 2006.

Sardiman, AM, Interaksi dan Motivasi Belajar Mengajar, Jakarta: PT.Raja Grafindo Persada, 2014

Syaiful Bahri Djamarah, Psikologi Belajar, Jakarta : PT. Rhineka Cipta, 2008

Sumiati dan Asra, Metode Pembelajaran, Bandung: Wacana Prima, 2008

Undang, Gunawan, Teknik Penelitan Tindakan Kelas, Sayagatama, Bandung, 2008.

Yamin, Moh, Teori dan Metode Pembelajaran, Madani, Malang, 2015.

Wahab Jufri, A, Belajar dan Pembelajaran Sains, Pustaka Reka Cipta, Bandung, 2017.

Vindri Catur Putri Wulandari, "Penerapan Pembelajaran Berbasis Praktikum Untuk Meningkatkan Keterampilan Proses Sains dan Penguasaan Konsep Siswa Kelas XI IPA 1 di SMA Muhammadiyah 1 Malang" (Universitas Negeri Malang)

Zainal Aqib dan Ali Murtadlo, Kumpulan Metode Pembelajaran Kreatif dan Inovatif, Bandung: Irama Widya

Zainal Aqib , Model-model, Media dan Strategi Pembelajaran Kontektual, Bandung : Yrama Widya.2017 